\title{
ALTERNATIVE COMMUNITIES IN RURAL SPACES. A WORLD OF OTHERS
}

\author{
Angel Paniagua ${ }^{A}$ \\ Received: May 8, 2020 | Accepted: June 23, 2020 \\ DOI: 10.5937/ZbDght2001051P
}

\begin{abstract}
This contribution is an analysis of difference between alternative communities and a case study of others in a community of others. There is no academic consensus in the geographical field about others ruralities. Through the exam of the alternative spaces is possible to advance in the interpretation of the difference and the others. We seek to give a big picture of the alternative communities in depopulated areas and the differences between them. The alternative communities grouped in the Red Iberica of Ecoaldeas are the empirical example with a specific case study: Tierras Altas in Soria (Spain). The technique of investigation in the documentary interpretation of its own sources: leaflets, advertisements, propaganda and information leaflets. A systematic inventory and analysis of the journalistic reports on these initiatives is a secondary source. In addition, geo-ethnographic methods are used in the case of study. The study reveals different-and even contrasted-types of rural alternatives in Spain, based in new form of difference/alternative (rural) lives in a specific and special place and singular housing. It are concluded that among the other alternatives there is no convergence in its self-definition, an open category. It constitutes the symbiosis between nature, community and individual. The relationship between others alternatives and the nature/land is a central element in the discourse, tactics and strategies. In addition, social exclusivity is one of the characteristics of many alternative settlements. It eliminates the conflict between traditional rural communities and new comers.
\end{abstract}

Keywords: alternative, others, marginality, community, rurality, Spain.

\section{INTRODUCTION}

Rural spaces are idealized places where it is possible to lead an alternative lifestyle with values different to urban ones and to take refuge from the dominant model of urban society (Whatmore, 1998). However, 'the vision of a peaceful rural community clearly excludes others who live in the countryside (...), the symbolic politics which requires a singular and homogenized view of rural society' (Sibley, 1995, p.107).

\footnotetext{
A Spanish Council for Scientific Research. Madrid. Spain; e-mail: angel.paniagua@csic.es
} 
There is no single accepted definition of alternative/or other(s) ruralities in Geography. Some authors suggest new forms of settled communities, differentiated principles from the traditional forms of rural communities (Woods, 2005) or reactionary alternative lifestyles in rural areas, associated with a purer rural space, based on social rural homogeneity (Cloke, 2006). From the perspective of alternative food geography, a dual category has been established defined by the opposition: conventional-alternative (Holloway et al., 2007). Meijertin, Huigen \& Van Hoven (2007, p. 42), under the name of 'intentional communities' suggest the existence of an alternative communitarian way of life outside mainstream society. Halfacree $(2007,1999)$ describes 'radical rural spaces' or 'radical ruralities', as lost academic categories of post productivism.

By studying alternative spaces progress can be made in the analysis of differences and the others. It is possible to find differences among the different ones and questions arise about the others among the acknowledged others, within an alternative community or between different alternative communities. In this contribution we intend, in a first part to study the difference between alternative communities and in a second the difference between others in an alternative community. The people who live in a community labeled as an alternative are the official others in a rural society: other community with other people.

Traditionally, geographers have studied the differences of marginalized 'others' in the (conventional) rural community (Valentine, 1997). From this perspective, the different others are linked to a group condition: children, the elderly, travellers, lesbians/ gays, ethnic minorities etc... (Valentine, 2001). If it is correct that the notion of marginalized other has been applied associated with conventional rural communities, there have been a series of previous contributions that have analyzed alternative communities (e.g. Philo, 1997). There have also been a series of social studies of alternative communities that have included populations located in rural areas (e.g. Chatterton \& Pickerill, 2010). In local conflicts, when the community represents itself as normal (Sibley, 1995, p. 28), the others represent the (social) alternative. Marginal groups tend to be morally and physically separate from the population -even in the same settlement-, a perspective passed down from political economics in rural studies (Cater \& Jones, 1989). This alternative character is revealed in relation to the (close or distant) establishment in a place. There have been fewer studies, however, of others in communities of others. A space exclusively of/for others may constitute a laboratory to observe the alternative in 'others' spaces'. Sibley (1995) suggests that the concept of 'the generalized other' presents 'fundamental implications for geographical studies of social interaction because it locates the individual in the social and material world' (Sibley, 1995, p. 9). This concept has been used to propose a purification of the space by dominant social groups in relation to the 'others' (Trudeau \& McMorran, 2011). In this work, it is used to study multiple others that share other(s) spaces, to purify the space from -the point of view- of the others. In this sense we want to analyze the different communities of alternative others, from a theoretical and academic positions that seek to amalgamate post-marxist points of view and environmental justice -present in the quoted works of David Harvey-, with others that come from political post-modernism, post-structuralism or feminist theory. They all agree in the relevance of the study of difference and marginality for the geographi- 
cal research of others. In this sense, this study aims to connect different academic orientations in the analysis of others, resistance, marginalization and difference. In words of Murdoch (2006) a new 'synthetic core of geography' around difference, marginality, resistance and the others.

\section{THE OFFICIAL RURAL OTHERS: SPACE, COMMUNITY OR PEOPLE}

The study of others has been conducted from the position of the subaltern, 'that of experiencing and living within the world as constructed by a dominant group, an experience in which one constructs one's own identity as an 'other' to the dominant' (Shurmer-Smith, 1994, p. 125). Constructing an individual or a group as other reflects an asymmetrical power structure that encompasses negative stereotypes (Sibley, 2008). The subaltern is identified with marginalized groups (Mitchell, 2007). The subaltern space would constitute the 'differential space', associated with a binomial view of power with social and spatial expression: spaces in the margins (Clayton, 2011). By studying others who want to live as others, it is possible to delve into the world of others, to imagine alternative and new worlds (hooks, 1990). As Harvey explains (2002, p. 224) it enables this transition from self to Self -or from the universal Person to the individual person (Philo \& Soderstrom, 2004, Paniagua, 2016) - who internalizes all others within one great other, where the focus is to explore relationships between others who live as others. Processes of self-differentiation and exclusion can be combined with processes of resistance to the outside world. In this case, all words must be redefined. This suggests alternative approaches in research into processes of 'othering' and in the intersection of different and competing micro and marginal points of view of others between others. It is also possible to establish minor individual resistance tactics by a process of distancing and living to overcome the dual politics of resistance associated with groups and social orientations. From this dual perspective, the difference arises from the power structures imposed by a given territoriality: 'hegemonic power universalized and containing differences in real and imagined spaces and places' (Soja 1996, p. 87). This conceals differences among individuals and social groups and micro spatial differences.

The other rurality presents three facets: first, a different space where one becomes established in a remote location: the margin as a space of alternative difference (Soja, 1996). A new dimension of spatial marginality as a space of social and individual creativity (hooks 1990) in which up lived alternatives can be considered (Sharp, 2011). The literature on alternative communities listed above would suggest that remoteness is not a universal feature, but in this contribution we pay special attention to alternative communities in remote and depopulated areas. In this case, the remote nature of the absolute space is used as a defence.

Alternative places which would constitute multiple spaces for ideological and social reasons. They would be other(s) spaces affected by permanent deconstruction and tentative reconstitution. It is a permanent process of becoming. To find other spaces there must first be a deconstruction of the space by abandonment, followed by a reconstruc- 
tion by means of an alternative (re)occupation in an imagined space. The other rurality delves into socio-spatial contradictions and would be a manifestation of a 'moral panic' (Cohen, 2002) in our contemporary (rural) society to encapsulate certain territorial differences. As Harvey (1989, p. 304) suggests: 'The space is fundamental in any form of communal life', to constitute unique spaces - 'heterotopies'- which oppose, or are different to others (Foucault, 1984, p. 252). In this line Valentine (1999) suggests that another place which would not only be the 'other' space, but a space imagined by its occupants. Second, a different community composed of people with shared ideals and lifestyles. The new politics of difference (Soja, 1996), establishes radical postmodernist practices of resistance by 'little tactics of the habitat' (Soja, 1988, p. 74), based on 'clandestine' tactics taken by groups and individuals opposing the normal style of social organization. As Bondi (1993) suggests, alternative identities are a part of a politics of resistance, in which the positions of identity politics forms part of emancipatory politics of resistance. These would not constitute a homogenization of the resistance, but would adopt multiple responses in different places. Each ecovillage would have a plural manifestation (individual or family). The multiplicity of resistances, by the construction of different worlds, would entail a remapping of spaces of difference (Soja \& Hooper, 1993). As Duncan suggests (1993 p. 39) this enables the 'discourses of the other distant the nature of other places and peoples'. Third, regarding the purity of the others, it is necessary to look for different individuals among the different ones, by following organisational guidelines and daily strategies. The essential other would be the different individual among the group of individuals who chose to live differently (Paniagua, 2016): the other among others -see case study in Tierras Altas-. The essence of 'each other lies in the interpretation of the difference between each other in relation to the others, by practices that single out each individual/other -micro places, distinctive house(s), own labour, family organization, garden land etc..- (Claval \& Entrinkin, 2004). These differences imply plural communities in the interpretation of otherness, with areas of collectivists and individuality within a process of creative (re) spatialization (Soja \& Hooper, 1993).

\section{METHODS}

The methods used in the research combine written texts and qualitative and (geo) ethnographic field work.

Documentary sources - This research analyses alternative communities by studying their own documentary sources (Forbes, 2000): pamphlets, publicity, advertisements, information leaflets etc.., and from newspaper articles about different initiatives. This research strategy can be used to develop other written discourses by a detailed analysis of simple texts and an exploration of the community's goals, origin, evolution, internal structure and relationship with the environment (Hoggart, Lees \& Davies, 2002 p 155). Communities of others share the desire to live a different life in an 'other' space, in a cultural nature under multiple expressions (Sibley, 1985). They reflect the extreme transition from modernity to rural post modernity. Doel (2010 p 127), following Deleuze, suggest that the world take place in difference. The experiences studied here form part of the Red Iberica de Ecoaldeas (Iberian Ecov- 


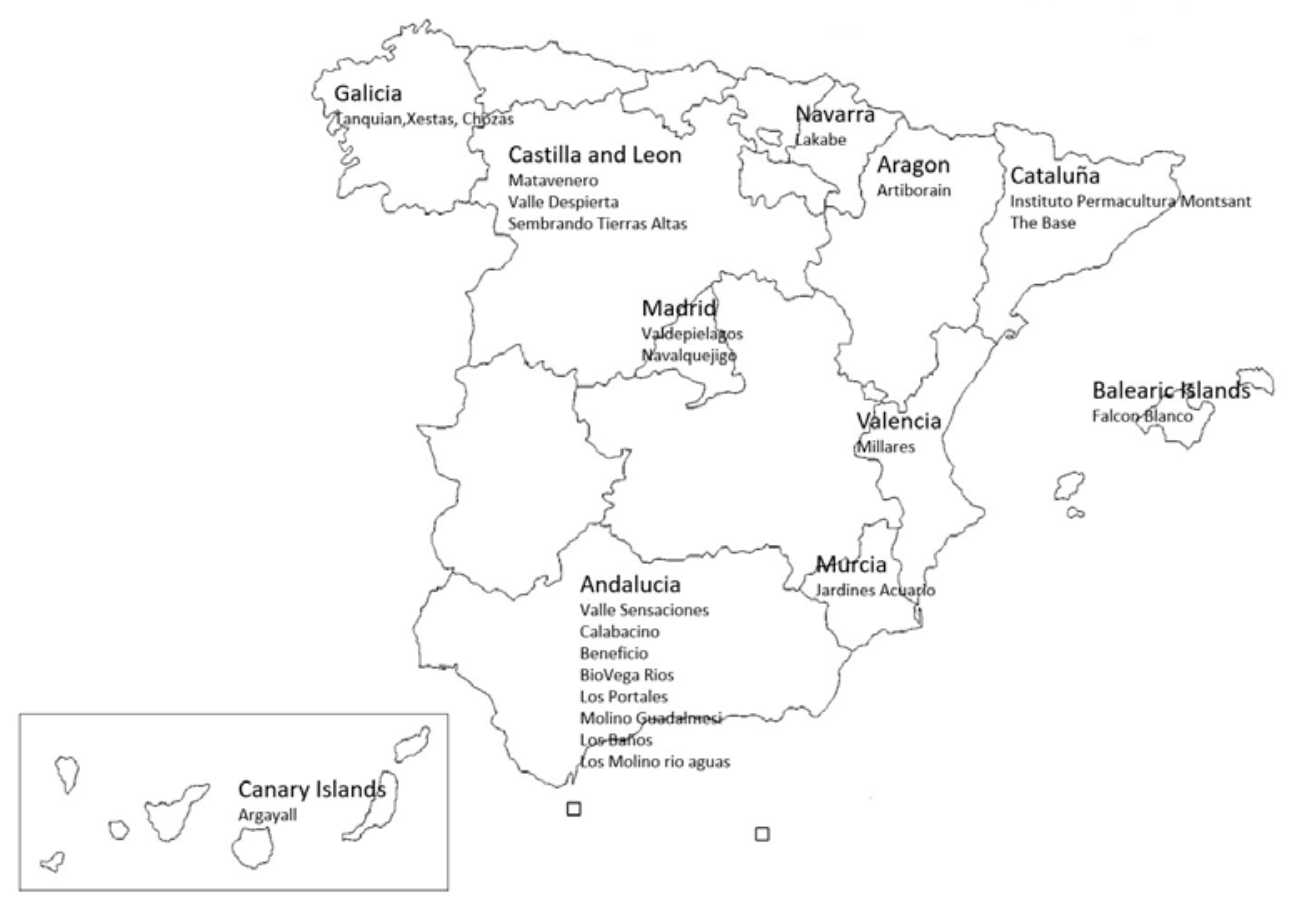

Figure 1. Main alternative communities analyzed

illage Network) that represents around 45 initiatives, of different orientations, in 12 regions. Since there is no census of alternative rural communities, the real number of these could actually be much higher. The life cycle of each initiative is variable, presumably short -an 'event of space' (Doel, 1999), so the ones considered here correspond to the most representative and oldest ones (Figure 1). This first research has its limitations, given that the written sources only have the utility of part of the studying the difference between alternative communities. In addition each text acquires a different meaning in relation to the community and the place where it is located. Due to this characteristic of the source, its comparison must be carried out in a critical manner: as text always present singular meaning, narratives and moral values, as ethic of events of spaces (Doel, 1999). The subjectivity is decentred as mode of identification (Murdoch, 2006, p. 10).

Case study - For this reason, we have completed the investigation a case study to understand the orientations within an alternative community in one of the most depopulated rural area of Europe. Namely, we focus on the unique case of Sembrando Tierras Altas (Figure 2), that merges the recovery initiatives of four abandoned villages in the north of the Soria province - by their previous inhabitants in cooperation with new alternative populations. The seasonal life of the previous inhabitants who identify with their pasts is linked to the newcomers' desire for a new alternative lifestyle, in clear transgression of the in/out duality. A study of the seasonal participant as observer in the spring-summer of 2017 is combined with a documentary analysis (Kears, 2000). Experimental (geo) ethnographies (Gregory, 1994) are oriented by the characteristics of a new and permanently reduced society and the intermittent presence of previous residents - 
including five interviews with key settlers and documentary sources. I have visited in an iterative way the main initiatives of the area, especially the most accessible ones; I have stayed days, with open conversations, while writing in the field notebook the main observations. He did not spend the night in the communities studied to respect his privacy (Hoggart, Lees \& Davies, 2002). The results have also been compared with those of a qualitative study carried out between 1998 and 1999 in Tierras Altas (Paniagua, 2000). This example is useful to understand alternative hybrid (Whatmore, 2002) communities between traditional and new populations and to analyze the others between others. This completes the first part of the research.

\section{TYPES OF RURAL OTHERS IN DEPOPULATED SPAIN}

Alternative settlement initiatives are expressions of a group of individuals seeking a different unconventional life with spatial distancing (Table 1). One of the pioneers of Valdepielagos (Madrid) defines an ecovillage as: 'A space in which a group of individuals lives together harmoniously and in harmony with nature. Those of us who live in an ecovillage are undergoing a transformation process to become closer to nature, to reduce our environmental impact and to create a culture of planetary peace and solidarity' (Valdepielagos, 2016).

Table 1. Rural others.

\begin{tabular}{|l|l|}
\hline Characteristics & Types of presentation \\
\hline Type of settlement & $\begin{array}{l}\text { Acquisition of own dwelling; occupation followed by transfer of the dwelling; } \\
\text { communal acquisition (E.g. Valle Sensaciones, Lakabe and Beneficio) }\end{array}$ \\
\hline Location & $\begin{array}{l}\text { Remote, bound, isolated, verified (e.g. Matavenero and Sembrando Tierras } \\
\text { Altas) }\end{array}$ \\
\hline Size & $\begin{array}{l}\text { No building, bioclimatic, restoration of traditional farmhouse (self-build, local } \\
\text { materials) (e.g. Valle Despierta, The Base). }\end{array}$ \\
\hline Social organization & $\begin{array}{l}\text { From one family to villages of } 250 \text { inhab. (e.g. Tanquian and Lakabe and } \\
\text { Calabacino). }\end{array}$ \\
\hline Social stratification & $\begin{array}{l}\text { Communal-hippie to individual. (Community life-family life). (e.g. Beneficio and } \\
\text { Chozas) }\end{array}$ \\
\hline Livelihood & $\begin{array}{l}\text { Leaders/ permanent group / occasional-seasonal (e.g. Beneficio, Falcon Blanco) } \\
\text { Community /individualization (e.g. Calabacino and Matavenero) }\end{array}$ \\
\hline
\end{tabular}

Source: own elaboration.

The other life (lives) has/have different perspectives, goals and characteristics. The multiplicity is a central aspect of alternative and marginality (Murdoch, 2006):

A differentiated place - The spatial preferences of the localization establish the characteristics of 'other places' (Harvey, 1989). A place of others where the others' discourses can be located (Duncan, 1993): 
First, one of the main distinctions is the type of settlement: (a) Squats, the settlement follows a procedure, first occupation and then purchase of the occupied dwelling by the inhabitants to achieve greater stability. This process entails more flexibility in the collective ideology. (b) Legal acquisition by the pioneer of a land extension on which to build dwellings and set up the community. This gives the settlement legal security ensuring its continuity.

Second, another characteristic is a distancing from conventional nuclei. This remoteness, the friction of distance (from the conventional world), is a barrier and a defence of human affairs. Depopulated areas of difficult access or location in large estates are preferred settlement areas. Space is not a container; on the contrary it has an active presence in the strategy of resistance and in social practice (Murdoch, 2006). Therefore, it is necessary to contextualize the strategies of resistance.

Third, choice of the location is also influenced by its physical characteristics: shelter from the elements (ravines), a contrast with arid surroundings (fluvial oases), unaltered or undegraded condition of the land and isolation because of difficult access (limited traffic, unmapped areas without road signs). These typical characteristics of the place search a feeling of protection, the natural demarcation of a micro-world different to its surroundings (Harvey, 1989). They help to distinguish it from the conventional world. In addition to topographic expression, toponymic originality is also important. One example is the Valle Sensaciones (Granada): 'Our fertile valley is a home in Mother Nature's lap; its ceiling is the night sky. A group of people can be safe here, protected from the sun, the wind and from prying eyes. In this place an intimate link develops between man and nature' (Sensaciones, 2016). In the alternative world, the original names of places are usually used. The essences of the place can, therefore, be symbolized (Soja \& Hooper, 1993): nature, constructed space and location.

The following places can be distinguished: First. Places abandoned by their original inhabitants (abandoned villages, old water or windmills and farmhouses) then later restored for an alternative lifestyle by the traditional owners or their descendants to conserve their identity. Second. Bio-ecological buildings in natural locations. Third. Farmhouses in which the original building has a new use-e.g. Cortijo los Portales -Seville.

The relevance of other housing. Ecovillages are characterised by a plural, sustainable and unique architecture, which reflects the values of the inhabitants. One example is the settlement started by a group of exurbanites from 1993-94 in Valdepielagos (Madrid province): 'Our first goal was to create a neighbourhood of 30 single family dwellings with bioclimatic architecture using environmentally-friendly materials. After an initial upheaval, in 2008 we began living here' (Valdepielagos, 2016). When there is no previous building, bio construction is often used as an expression of sustainable building integrated with nature. It combines the restoration of traditional architecture and the imaginary home.

The community with others - A new lifestyle is often a strong motivation for settling into a community with other people (Valentine, 2001). There are different modalities:

First. Ruralist. One of the most radical forms of this type of alternative lifestyle is when communities take over abandoned villages (Soja, 1988). Gradually, these communities reach cession agreements with the owners, especially with publicly-owned buildings 
in order to guarantee the settlement. Due to possible conflict, the influence of the media and the benefits for landscape management all help the process of the transfer of use to the new community. The initial precariousness is a resistance strategy and encapsulates political potential (Waite, 2009) for permanence in the place. In this case, the alternative identities are a relevant part of a comunitary politics of resistance (Bondi, 1993). There are several examples of this modality. One important can be seen in the alternative community of Lakabe -Navarra- which occupied the entire village in the Eighties. This village grew from having just one initial usable dwelling to having around 50 inhabitants in different dwellings. It also recovered its village council. The village functions as a community: 'the economy, decisions, work and leisure are all community activities' (Comunidad Lakabe, 2016). They have revitalized rurality as a way of life. The Artiborain Association in the Huesca Pyrenees represents the occupation experiences of three villages: Aineto, Artosilla and Ibort. The return to rurality is a way of creating 'an alternative model of a society of an inspiring collective project with which to deal with a daily life linked to nature' (Nuevos pueblos, 2012). Aineto is a key example in the neorural movement: Exurbanites have repopulated this village since the nineteen seventies. At the end of the Eighties, the authorities handed over the village to the Artiborain Association, which, together with Artosilla and Ibort, is responsible for its administration.

Another example is the community El Calabacino, in the village of Alajar (Huelva), abandoned in the 1960s. Its repopulation began a decade later, first by squatters, who later purchased the houses from the previous private owners. The first alternative stage moves on to another community-individual phase, with peculiar characteristics: a lack of vehicles and the self-sufficiency of the inhabitants. Ecology based on difference (Murdoch, 2006) as a part of the process of de/re-territorialization. Private ownership of the houses implies a private dimension and a community dimension in relation to public spaces. It currently has 230 inhabitants (Rodríguez, 2008).

Another type of settlement can be found in the village of Matavenero (Torre del Bierzo-León), which has been self-managed since 1989 by the international green movement Rainbow (Ecoaldea de Matavereno, 2016). Since its repopulation there has been a steady acquisition of abandoned traditional old houses. This village is an exclusive alternative community (Willians, 1973): all the new inhabitants must pass a 12-month trial period. This exclusivity for admission into an alternative community also appears in other experiences, as a return to an organic rural community (Williams, 1973), with a shared family social structure and resources. It is currently defined as a 'rebuilt village', based on private property and a family economy, in which areas of daily lives are shared (Ecoaldea de Matavenero, 2016; Soja, 1996): 'Matavenero is a rebuilt village, not a community, although we do share many areas of our daily lives, activities, spaces etc (...), with private properties coexisting with independent family economies' (Matavenero, 2016).

One conflictive example of occupation is the village of Navalquejigo in the Northeast of the Madrid province, which has undergone successive episodes of occupation and expulsion (Comes, 2012). The village was occupied by exurbanites in 1997 after having been completely abandoned in 1989. All new members must be approved by the group. It currently has a population of between 10 and 15 inhabitants and around 13 restored houses (Lancho, 2008). 
Second. Hippie. One example of the hippie community is the Beneficio Commune in Granada, which follows a collective lifestyle (Cloke, 2006). This was started at the end of the 1970s by two English people who 'released their land' by purchasing it with donations and making it available for use by individuals seeking an alternative lifestyle (Ruiz, 2016). This is one of the most long-standing hippie communes in Europe, without topographical significance reflected by its voluntary absence from all maps (Soja, 1988).

Thrid. Agroecology. Other communities pursue their alternative nature by means of organic farming and exchange programs for work, skills and knowledge. Their aim is to be self-sufficient for food produce (Bio-Vega de los Ríos, 2016, Instituto Permacultura Montsant 2016). In the village of Millares -Valencia- another initiative consists in growing organic crops on abandoned terraces acquired from the previous owners. Another life project is that of bioconstruction (Asociación, 2013). The ecovillages in Galicia: Tanquian (Lugo), Xestas (Coruña) and Chozas (Pontevedra) are three experiences of architectonic and environmental restoration of abandoned villages using traditional skills, in which the properties are purchased or handed over from the previous owners or councils. The inhabitants are alternative ex-urbanites who have become organic livestock farmers (Galicia rural, 2016).

Fourth. Spiritual. Los Portales Estate -Seville- is an example of a spiritual community. It was an old manor house and now combines a sense of community with a personalized orientation within a setting of pastureland. In this case, the community is a social space of individual creativity (hooks, 1990). This spiritual community aims to be selfsufficient with regards to food produce (Los Portales, 2016). An alternative community has also established itself on the Argayall Estate (Gomera, Canary Islands), which is occupied by around 20 individuals seeking personal transformation, supervised by a permanent group that runs the establishment, which borders on conventional hotel management (Finca Argayall, 2016). Finca Arcadia -Girona-, which covers an area of 15 hectares has a similar focus and is run as a cooperative. This is used for retreats for personal meditation (Arcadia, 2016).

Five. Bio-constructive. The alternative nature of this type of community lies in its construction with natural materials and energy self-sufficiency. This is the case of El Valle Despierta (Avila), a community of 10 people living on private plots of land and sharing common areas. Coexistence is based on interpersonal trust (Valle Despierta, 2016). With the rural life, ideals of freedom can be developed in a natural setting. Bioconstruction forms the basis of the initiative called The Base -Girona-, a restored aerodrome, which focuses on social teaching and education in an alternative lifestyle (The Base, 2016)

Sixth. Returned inhabitants. Based on solidarity for reconstruction of abandoned towns by people who returned or their descendants, together with newcomers. This is the case of Sembrando Tierras Altas - in northeast Soria- (Sembrando Tierras Altas, 2016). A repopulation and restoration rural building project with a conventional lifestyle based on private property.

Living between others - Usually in geography the 'others' are studied in relation to differences with the conventional community, on the contrary few studies have focused on internal differences (Harvey, 2002). Leaders and power structures also appear in al- 
ternative communities (Harvey, 1989); they are not totally egalitarian communities. The leader is habitually the owner of the site selects the community and sets the alternative goal. Desertion or death of the leader indicates a start to the decline of the alternative community. There are, also, different degrees of community adherence: in community/out of community of others. Different groups (and individuals) have different meanings depending on their use of space and time (Soja, 1996). The alternative spaces they are intimately associated with (multiple) alternative meanings of identities. The space he does not drive new alternative and pluralist social relations (following Deleuze, see Doel 2010).

There are different models of other(s) social organization: First, communities established in villages or hamlets that combine family and community life, the private property of each family and respect for individual values (Sharp, 2011). They share community ideals and life centres on each family's or individuals' aspirations. Second, community life in which there is no partial ownership as the site is owned by the individual who started the settlement. There are three stages to this process: settlement of the leaders (the owners of the land); settlement of a small permanent group of people on the site; finally, the admission of collaborators who 'learn' to be alternative. Temporary self-built or temporary constructions predominate. These seasonal alternatives live a conventional life part of the year to save and be able to live as 'others' the rest of the time. One example is the hippie commune Beneficio (Granada), which groups together around 250 people from several European countries, united by a life related to nature. Third, educational communities with few permanent individuals and 'others' in a seasonal basis to learn an alternative lifestyle.

The academia of othering - Teaching to be a rural other can form the basis of the alternative community. This can entail tasks of organization, community life and green building. The distinguishing characteristic of the community Sensaciones in the Alpujarras -Granada- is that it aims to be a laboratory to learn to become integrated as part of nature, through authenticity and creativity (Valle de Sensaciones 2016). As Foucalut (1984) explain the territory is a becoming for new potentials as consequence of multiple combinations of social and spatial relations. This is often associated with a degree of antiurban feeling: 'many people living in the cities are frustrated with human culture (...). That's why we decided to transform the Valle de Sensaciones' (Valle de Sensaciones 2016). Other experiences include that of FalconBlanco - Ibiza (Balearic Islands)-, an old remote country house far from tourist centres, which currently functions as a Centre of Meditation, maintained by work exchanges (Falcon Blanco, 2016).

Other experiences such as the Molino de Guadalmesí (Cadiz), constitutes 'a space to learn community living' led by a group of seven individuals who educate visitors in a new lifestyle. Their main goals are to disseminate this life experience and also to finance the running of the community (Molino de Guadalmesí, 2016). The Cortijo los Baños -Almeria/Andalusia- also has an educational approach in 'a space to awaken your senses and connect with nature....' (Cortijo Al-Hamanan 2016). This space offers training courses in environmental education and personal development. Similar goals can be found at Los Molinos del río Aguas (Almeria) and the Finca jardines de Acuario in Totana-Sierra Espuña (Murcia), which constitutes a comprehensive project 'tucked away in 
the woods'-, with participatory management of local and cultural resources (Asociación Jardines de Acuario, 2016).

\section{THE CASE STUDY OF SEMBRANDO TIERRAS ALTAS (SORIA)}

A unique case of alternative rural repopulation can be found in the initiative Sembrando Tierras Altas, one of the most depopulated regions in Europe. Its originality with respect to the rest of the initiatives is its hybrid character (Whatmore, 2002) -traditional population and alternative new populations- in front of the usual exclusive character of other alternative communities.

The evolution of Tierra Altas is marked by a loss of population, changes in local institutions and in land use (Paniagua, 2000). Emigration from the area is motivated by a shortage of job opportunities. Depopulation has produced a concentration in local power as 18 municipalities disappeared and became annexed to the head municipality of the area (Figure 2). The loss of administrative and political identity exacerbates the depopulation and aging processes. A third of the population has retired which is perceived as negative for the future: 'here we're all old people or pensioners'. The loss in population has resulted in abandonment of 20 population nuclei and the forestry commission has taken over a large proportion of the land (more than $60 \%$ of the area) This conditions the subsequent (re)appearance of new land uses.

This abandoning of the land is articulated with a selective immigration process and a collective approach to repopulation. The immigration process corresponds to over $12 \%$ of the area's population during the 1990s and is associated with three phenomena ( $\mathrm{Pa}$ niagua, 2000): The first forms seasonal migration, concentrated in the summer and local holidays. This seasonal migration takes place in the main nuclei of the area and in depopulated nuclei and is linked to the associationist movement for the architectural and social recovery of abandoned villages. This group is comprised by previous inhabitants and their descendants. Around $60 \%$ of houses in the area are second homes. The second form return migration, mainly by family groups with children of working age affected by processes of economic reform and urban recession. They function as 'dynamizing agents' in the area. The third form new migrants from new social groups that settle in accessible villages to mainly start rural tourism enterprises to neo-rurals that settle in remote depopulated nuclei with the aim of restoring them and leading an alternative life.

This context of socio-demographic change generates local restructuring programs: changes in use of agricultural land; new forestry management practises for the recovery of abandoned villages and the practice of leisure activities (trekking, etc): rural tourism activities associated with returning populations or new social groups. These socioeconomic processes have generated a demographic revitalization since 1990 and a positive outlook for the future of the area.

The initiative Sembrando Tierras Altas fits into this context arising from abandoned villages that became materially and socially revitalized. It is an inclusive project of moral repopulation in the villages of Tierras Altas. This recovery process synthesizes the 


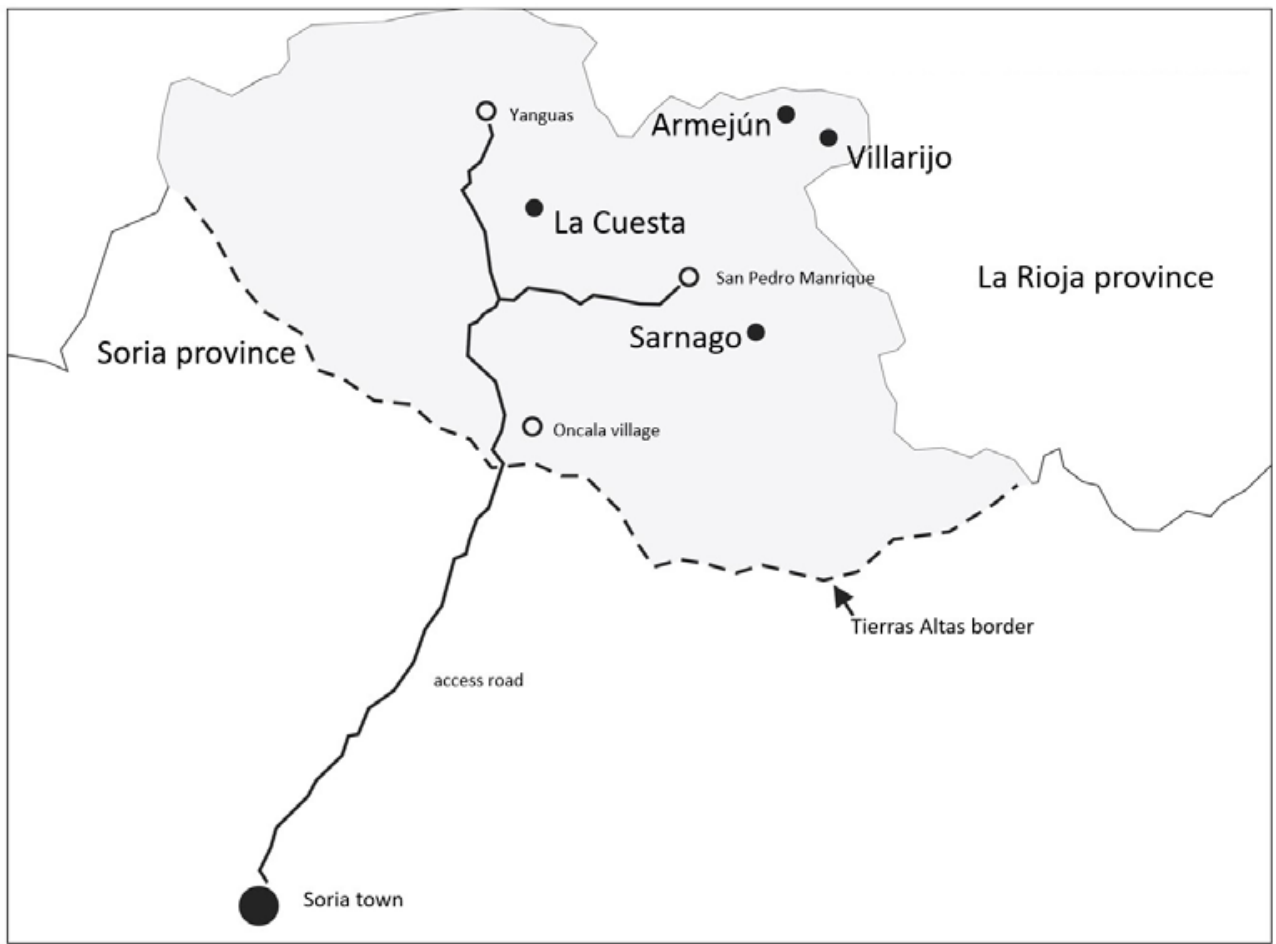

Figure 2. Sembrando Tierras Altas communities

concern of the previous inhabitants' and their descendants to maintain the villages for temporary visits and the settling in of newcomers who collaborate in the villages' restoration projects. It constitutes a unique and non-conflictive symbiosis between local populations and new inhabitants where a permanent social life is guaranteed, although with some instability, by the exurban or international population. It is a case of in/out interaction, a shared project between the owners of the properties and the new inhabitants who ensure continuity to village life and restoration of the village (Vuelta al Campo, 2017).

The legacy of the depopulation process acquires a positive dimension: untarmacked roads, conservation of the traditional architecture and the rural environment and of primitive accesses etc. The initiatives are concentrated in four nuclei: Sarnago, La Cuesta, -near to San Pedro Manrique- (Sembrando Tierras Altas, 2016), Armejun, and finally the most remote and inaccessible Villarijo (Figure 2):

Sarnago - This is an interesting project in which the return of previous inhabitants in the Eighties prevented its complete depopulation (Ridruejo, 1984). In 1980, the Association of Friends was founded with the aim of rebuilding the town hall and collective spaces and recovering local traditions. It currently has over 130 members. Its motto 'Sarnago, land of all, land of no-one', expresses its intermittent spirit, recovered by its previous inhabitants. In 1987, the last birth took place there since the Seventies (Hermoso, 2016). 
La Cuesta - developed over a three-stage process of abandonment and recovery: first, it was first occupied as a centre for drug rehabilitation; second, around the year 2000 previous inhabitants began to return on a seasonal basis; third, new exurban inhabitants settled in the area seeking a sustainable rural life. These new inhabitants- currently 6 individuals - have purchased their houses (La Cuesta, 2015) and work restoring the village and tending their allotments and goats. A rural house has also been opened as holiday accommodation by a businessman in the area.

Armejun - this village lost its population in the Sixties (Sembrando Tierras Altas, 2015) and its material patrimony of around 50 houses was mostly overgrown and in ruins. In 1990, around 25 years after its depopulation, the Armejun Friends' Association was founded, composed of previous inhabitants from the village, with the purpose of rebuilding it and repopulating it on a seasonal basis. Since 2013, a small number of neorural young people have moved there to help restore the village and to lead (semi)isolated lives. They run a social project in symbiosis with the association of previous inhabitants to restore - 'in a traditional and bio-sustainable way'- and repopulate the village, 'with a long term view to living and working in the countryside'. An original pioneering neo-rural couple and a young university student who joined them a few years later (from the Basque country and from abroad, respectively) have held out. Their goal is alternative self-sufficiency (Belled, 2016).

Villarijo - is a village that was abandoned during the nineteen sixties. The friends' association was started up in the nineteen nineties to prevent the collapse of 50 houses. A family of two new inhabitants from the Basque country has lived there since 2010 leading a (semi)isolated alternative life, tending livestock and restoring the village (Villarijo, 2015). Previous owners, or their descendants, reside in the area on a seasonal basis.

The case of Sembrando Tierras Altas presents some unique characteristics: the relevance of civil and cultural associationism in the restoration of villages; solidarity between previous and new inhabitants for a continuation of village life in the context of a common social project of local revitalization, the recovery of traditions, spaces and public buildings (Claval \& Entrinkin, 2004). Few people are capable of revitalizing a place, far away from the conventional world, across the in/out or self/other frontiers (Whatmore, 2002) as new meeting points (Massey, 2005) between new and traditional.

\section{CONCLUSION}

It is necessary to advance in the geographical reconsideration of the others, differences, subordination and spatial marginality. This difference would take a positive value across its dimensions, a (new) view of the others (Del Casino, 2009). The idea of rural other is that they are diverse and the term in not restrictive. Among the alternative others there is no convergence in its definition. This oscillates, as an open category, between community, individuality, nature, self-management, as an expression of essential ways of living. These enable each person to be identified in his/her place and constitute a symbiosis between nature, community and individual. They also entail a return from the globalization process and loss of identity, or a move backwards- in time - to a rural 
and ancestral world. In this contribution we wanted to advance in the geographical debate of definition and categorization of the alternative others, establishing different categories and manifestations.

The relationship between the alternative others and nature/land is central in the discourse and strategies of (re)creation of a (new) territoriality. The particular environmental qualities of a place (Harvey, 1996), are key to its selection and to the politics of resistance. They create imagined spaces (Harvey, 1989) of the alternative community. They express a transition between 'the power to resist to resisting power' (Sharp, Routledge, Philo \& Paddison 2000), to create multiple communities of resistance with many radical and alternative subjectivities (Soja \& Hooper, 1993). This postmodern geography approach is manifest in alternative communities, which share common traits but also different views of the other world (Doel, 2010). Each case presents particular tensions between resistance and complicity (Doel, 1999; Harvey, 2001), from communities in which the identity is diluted in the collective to alternative communities of individuals with a common view of the collective space (Paniagua, 2016). Unfortunately the alternative rural communities cover the margins or the interstices of (rural) space and politically and academically block 'more serious political engagement' (Massey, 2005, p. 103).

Social exclusivity is a trait of many alternative settlements. Conformity with the group is a condition for settlement. 'Social exclusivity' expects the members' mutual and solidarity concern in relation to the external world. In definitive, this ideal pretends to identify oneself as the other in a world of others. The alternative world is identified by diversity in difference and difference in diversity. A way of perform the resistance in an imagined and attained world. The way to generate a new social space with distinctive, intra relational and differential dimensions (Kuus, 2013). With a fixed identity linked to traits of the alternative world and a contingent identity that singles out each settlement. Bounded and community are linked. Alternative communities involve a difference with the external world and internal plurality among others, in a new world of and between- others.

The world of the others breaks the traditional conflict of rural communities between locals and newcomers. The relationship between the generalized other and the particular other (Sibley, 1998) produces the essential other: a deep other in the world of others. As Harvey (2002 p. 224), suggest in the words 'grand other' with respect to relationships of solidarity with others who aspire to live their lives in different material circumstances and emotional worlds. In short, the difference or the alternative -space or community- becomes a pure category, without opposite. Only in the case of study the alternative leads to a new locality or hybrid space. In this way, this paper can contribute to the debate about the nature of the others in the social and rural geography.

Acknowledgement by the constructive comments of a referee. This paper was presented at the annual conference of British Geographers (2017), with the title 'Alternative rural spaces: The essential other'. 


\section{REFERENCES}

Arcadia (2016). Arcadia. http://www.arcadia.cat./es Accessed on May 25, 2020.

Asociación Benéfico Social Nicolás Tesla (2013). Proyecto ecoaldea Las Fuentecicas. http://absntesla.blogspot.com.es/2013/ Accessed on May 25, 2020.

Asociación Jardines de Acuario (2016). Asociación Jardines de Acuario (Totana-Sierra Espuña). http://jardinesdeacuario.com/acuario/ Accessed on May 25, 2020.

Belled, S. I. (2016). Los habitantes de Armejún abren las puertas del pueblo a nuevos vecinos.Heraldo de Soria 13/3/2016 http://www.heraldodesoria.es/ Accessed on May $25,2020$.

Bio Vega de los Ríos (2016). Bio Vega de los Ríos. http://www.ecoalternativa.net/Accessed on May 25, 2020.

Bondi, L. (1993). Locating identity politics. In: M. Keith \& S. Pile, eds. Place and the politics of identity, pp. 82-99. London: Routledge.

Cater, J., Jones, T. (1989). Social Geography. An introduction to contemporary issues. London: Edward Arnold.

Chatterton, P., Pickerill, J. (2010). Everyday activism and transitions towards post-capitalist worlds. Transactions of the Institute of British Geographers, 35 (4), pp. 475-490.

Claval, P., Entrinkin, N. J. (2004). Cultural geography: place and landscape between conttinuity and change. In: G. Benko \& V. Strohmayer, eds. Human geography. A history for the 21st century, pp. 25-46. London: Arnold.

Comes, M. (2012). Un pueblo en secreto. http://ccaa.elpais.com/ccaa/. Accessed on $5 / 10 / 2016$.

Comunidad Lakabe (2016). Experiencias Comunidad lakabe. https://www.lakabe.org/ Accessed on May 25, 2020.

Clayton, D. (2011). Subaltern space. In: J.A. Agnew \& D.N. Livingstone, eds. The Sage handbook of geographical knowledge, pp. 246-260. London: Sage.

Cloke, P. (2006). Rurality and racialized others: out of place in the countryside. In P. Cloke, T. Marsden, \& P.H. Mooney, eds. Handbook of rural studies, pp. 379-387. London: Sage.

Cohen, S. (2002). Folk devils and moral panics. London: Routledge (third edition).

Cortijo Al-Hamam (2016). Cortijo Los Baños Al-Hamam. https:/oasisalhamam.com/ Accessed on May 25, 2020.

Del Casino, V.D. (2009). Social geography. Oxford: Wiley-Blackwell.

Doel, M. (1999). Poststructuralist geographies: the diabolical art of spatial science. Edinburgh: Edinburgh Univ. Press.

Doel, M. (2010). Representation and difference. In: B. Anderson \& P. Harrison, eds. Taking-place: Non representational theories and Geography, pp. 117-130. London: Ashgate.

Duncan, J. (1993). Sites of representation. Place, time and the discourse of the other. In: J. Duncan \& D. Ley, eds. Place/culture/representation, pp. 39-56. London: Routledge.

Ecoaldea de Matavenero (2016). Matavenero-León. https://danieleleoz.com/2018/12/13/ matavenero-ecoaldea-hippie-el-bierzo/ Accessed on May 25, 2020. 
Falconblanco (2016). What is FalconBlanco? http://falconblanco.com/allabout.html Accessed on May 25, 2020.

Finca Argayall (2016). Finca Argayall-La Gomera. http://www.en.argayall.com/ Accessed on May 25, 2020.

Forbes, D. (2000). Reading texts and writing Geography. In: I. HAY, eds. Qualitative research methods in human geography, pp. 122-143. Oxford: Oxford University Press.

Foucault, M. (1984). The Foucault reader. -P. Rabinow, ed.- New York: Pantheon Books.

Gregory, D. (1994). Social theory and human geography. In: D. Gregory, R. Martin, \& Smith, G., eds. Human geography: society, space and social sciences, pp. 78-112. London: McMillan Press.

Galicia Rural (2016). Las 'eco aldeas' recuperan pueblos del rural abandonados con actividad agro ganadera ecológica y sostenible. http://www.europapress.es/galicia/ Accessed on May 25, 2020.

Halfacree, K. (1999). A new space or spatial effacement? Alternative futures for the postproductivist countryside. In: N. Walford, J.C. Everith, \& D.E. Napton, eds. Reshaping the countryside: perceptions and processes of rural change, pp. 67-76. Wallingford: CABI.

Halfacree, K. (2007). Trial by space for a 'radical rural': introducing alternative localities, representations and lives. Journal of Rural Studies, 23, pp. 125-141.

Harvey, D. (1989). The condition of postmodernity: an inquiry into the origins of cultural change. Oxford: Blackwell.

Harvey, D. (1996). Justice, nature and the geography of difference. London: Blackwell.

Harvey, D. (2001). Spaces of capital: towards a critical geography. Edinburgh: Edinburgh Univ. Press.

Harvey, D. (2002). Spaces of hope. Edinburgh: Edinburgh Univ. Press.

Hermoso, B. (2016). Un pueblo muerto... y ahora resucitado. El País, 18/8/2016. http// cultura.elpais,com/ Accessed on May 25, 2020.

Hoggart, K., Lees, L., Davies, A. (2002). Researching human geography. London: Arnold.

Holloway, L., Kneafsey, M., Cox, R., Venn, L., Dowler, E., Tuomaimen, H. (2007). Beyond the 'alternative'-'conventional' divide? Thinking differently about food production-consumption relationships. In: B. Mayer, L. Holloway \& M. Kneafsey, eds. Alternative food geographies, pp. 77-93. Emerald: Bingley.

Hooks, B. (1990). Marginality as site of resistance In: R. Ferguson, H. Gever, J. MinhaHa, C. West, eds. Out there: marginalization and contemporary cultures. Cambridge, pp. 341-343. Mass: MIT Press.

Kears, R. (2000). Being there: research through observing and participating. In: I. Hay, eds. Qualitative research methods in human geography, pp. 103-121. Oxford: Oxford University Press.

Instituto Permacultura Montsant (2016). Una escuela de aprendizaje práctico de Permacultura. http://www.permacultura-montsant.org/ Accessed on May 25, 2020.

Kuus, M. (2013). Places of lower Rank: margins in conversations. Political Geography 37, pp. 30-32.

Massey, D. (2002). For space. London: Sage. 
Matavenero (2016). Matavenero. http://www.matavenero.org/vidacomun.html. Accessed on May 25, 2020.

Meijertin, L., Huigen, P., Van Hoven, B. (2007). Intentional communities in rural spaces. Tijdschrift voor Economische en Sociale Geografie 98 (1), pp. $42-52$.

Mitchell, K. (2007). Geographies of identity: the intimate cosmopolitan. Progress in $\mathrm{Hu}$ man Geography 31(5), pp. 706-720.

Molino de Guadalmesí (2016). Molino de Guadalmesí. https://www.ecoalternativa.net/ item/molino-de-guadalmesi/ Accessed on May 25, 2020.

Murdoch, J. (2006), Post-structuralist geography. London: Sage.

Nuevos Pueblos (2012). Aineto, Artosilla e Ibort (Asociación Artiborain): más de 25 años de repoblación y rehabilitación. http://nuevospueblos.blogspot.com.es/2012/ Accessed on May 25, 2020.

La Cuesta (2015). La Cuesta -Sembrando Tierras Altas. http://agendasocialdesoria.com/ team/sembrando-tierras-altas/ Accessed on 9/1/2017.

Lancho, B. (2008). Los 'okupas' vuelven a navalquejigo. http://www.elmundo.es/ Accessed on May 25, 2020.

Los Portales (2016). Finca Los Portales. http://www.losportales.net/ Accessed on May 25, 2020.

Paniagua, A. (2000). Migrantes, lideres y reestructuración rural en áreas desfavorecidas del interior. Un caso de estudio. In: Actas del X Coloquio de Geografía Rural de España, pp. 339-345. Lérida: University of Lérida.

Paniagua, A. (2016). An individual rural geography. The Professional Geographer 68(3), pp. 511-518.

Philo, Ch (1997). Of Other rurals? In: P. Cloke \& J. Little, eds. Contested Countryside Cultures, pp. 19-50. London: Routledge.

Philo, Ch., Soderstrom, D. (2004). Social geography: looking for society in its spaces. In: G. Benko \& V. Strohmayer, eds. Human geography. A history for the 21st century, pp. 105-138. London: Arnold.

Ridruejo, C. (1984). Emigrantes sorianos vuelven al pueblo que dejaron hace 20 años. El País, 3/9/ 1984. http://elpais.com/ Accessed on May 25, 2020.

Rodríguez, T. (2008). El calabacino, una aldea de Alájar donde se practica el neorruralismo. http://www.huelvainformacion.es/Accessed on May 25, 2020.

Ruiz, A. (2016). 24 horas en la mayor comuna hippie de España. El Mundo, 25/05/2016. http://www.elmundo.es/sociedad/2016/05/25. Accessed on May 25, 2020.

Sembrando Tierras Altas (2015). Armejún-Sembrando Tierras Altas. http://agendasocialdesoria.com/team/sembrando-tierras-altas/ Accessed on May 25, 2020.

Sembrando Tierras Altas (2016). Sembrando Tierras Altas. http://agendasocialdesoria. com/team/sembrando-tierras-altas/ Accessed on May 25, 2020.

Sharp, J. (2011). Subaltern geopolitics: introduction. Geoforum 42, pp. 271-273.

Sharp, J.P., Routledge, P., Philo, CH. \& Paddison, R. (2000). Entahglements of power. Geographies of domination/resistance. In: J.P. Sharp, P. Routledge, CH. Philo \& R. Paddison, eds. Entangements of power: geographies of domination/resistance, pp. 1-42. London: Routledge.

Sibley, D. (1995). Geographies of exclusion. London: Routledge. 
Sibley, D. (1998). Problematizing exclusion: reflections on space, difference and knowledge. International Planning Studies 3, 1, pp. 93-100.

Sibley, D. (2008). Self-other. In: R. Kitchin \& N. Thrift, eds. International Encyclopedia of Human Geography. pp. 85-88. London: Elsevier.

Shurmer-Smith, P., Hannam, K. (1994). Worlds of desire, realms of power: A cultural geography. London: Edward Arnold.

Soja, E. (1988). Postmodern geographies: the reassertion of space in critical social theory. London: Verso.

Soja, E. (1996). Thirdspace: journeys to Los Angeles and other real-and-imagined places. Cambridge: Blackwell.

Soja E., Hooper, B. (1993). The space that difference makes. Some notes on the geographical margins of the new cultural politics. In: S. Pile \& M. Keith, eds. Place and politics of identity, pp.180-202. London: Routledge.

The Base (2016). Un aeródromo reciclado en ecoaldea en el Alt Empordà. http://labase2001.blogspot.com/Accessed on May 25, 2020.

Trudeau, D., McMorran, CH. (2011). The geographies of marginalization. In: V.J. del Casino, M.E. Thomas, P. Cloke \& R. Panelli, eds. A companion to social geography. pp. 437-453. London: Blackwell.

Valdepielagos (2016). Ecoaldea de Valdepielagos. Un lugar para vivir. http:www.ecoaldeavaldepielagos.org. Accessed on May 25, 2020.

Valentine, G. (1997). Making space. Lesbian separatist communities in the United States. In: P. Cloke \& J. Little, eds. Contested countryside cultures. Otherness, marginalization and rurality, pp. 109-122. London: Routledge.

Valentine, G. (1999). Imagines geographies: geographical knowledges of self and other in everyday life. In: D. massey, J. allen \& P.H. Sarre, eds. Human Geography today. pp. 47-61. Oxford: Polity Press.

Valentine, G. (2001). Social geographies. Harlow: Pearson.

Valle de Sensaciones (2016), http://sensaciones.de/es/. Accessed on May 25, 2020.

Valle Despierta (2016). El Valle Despierta. https://ecovillage.org/project/el-valle-despierta/ Accessed on May 25, 2020.

Villarijo (2015). Villarijo -Sembrando Tierras Altas. http://agendasocialdesoria.com/ team/sembrando-tierras-altas/ Accessed on May 25, 2020.

Vuelta al Campo (2017). Vuelta al campo, vivir en una eco-aldea. http://agendasocialdesoria.com/team/sembrando-tierras-altas/ Accessed on May 25, 2020.

Waite, L. (2009). A place and space for a critical geography of precarity? Geography Compass 3/1, pp. 412-433.

Whatmore, S. (1998). Nature's refuge? Rethinking rural environments. Environment and Planning A 30, pp. 1149-1150.

Whatmore, S. (2002). Hybrid Geographies. London: Sage.

Willians, R. (1973). The country and the city. London: Chatto.

Woods, M. (2005). Rural geography. London: Sage. 


\section{CONFLICTS OF INTEREST}

The author declared no potential conflicts of interest with respect to the research, authorship, and/or publication of this article.

(C) 2020 by the authors. This article is an open access article distributed under the terms and conditions of the Creative Commons Attribution (CC BY) license (http://creativecommons.org/licenses/by/4.0/). 